\title{
РОЗВИТОК ІДЕЙ ПСИХОАНАЛІТИЧНОЇ ПЕДАГОГІКИ В НАУКОВО-ПРАКТИЧНІЙ ДІЯЛЬНОСТІ АННИ ФРЕЙД
}

У статті окреслено життєвий та професійний илях британського психолога і психоаналітика Анни Фрейд. Побіжно розглянуто деякі ї̈ праці й погляди шзодо взаємодії психоаналізу і педагогіки. Розкрито особливості роботи приватної школи «Хітиинг»у Відні та Хампстедського дитячого будинку в Лондоні, до створення яких А. Фрейд доклала чималих зусиль. Представлено докази того, щчо вчена підтримувала концепцію вільного виховання М. Монтессорі, критикуючи при иьому директивну педагогіку і класичну систему освіти. Доведено, щзо завдяки впровадженню ідей психоаналізу в систему освіти почали звертати увагу на внутрішній світ учителя та учня, сферу несвідомого, а також на питання внутрішніх конфліктів особистості.

Ключові слова: психоаналітична педагогіка, освіта, психоаналіз, виховання, Анна Фрейд.

В статье раскрыт жизненный и профессиональный путь британского психолога и психоаналитика Анны Фрейд. Бегло рассмотреньл некоторые ее работьл и взгляды относительно взаимодействия психоанализа и педагогики. Описаны особенности работы частной школьы «Хитичнг» в Вене и Хампстедського детского дома в Лондоне, к созданию которых A. Фрейд приложила немало усилий. Представлень доказательства того, что ученая поддерживала концеепцию свободного воспитания М. Монтессори, критикуя при этом директивную педагогику и классическую систему образования. Доказано, что благодаря внедрению идей психоанализа в систему образования начали обращать внимание на внутренний мир учителя и ученика, сферу бессознательного, а также внутренние конфликты личности.

Ключевые слова: психоаналитическая педагогика, образование, психоанализ, воспитание, Анна Фрейд.

The development of the ideas of Psychoanalytical Pedagogy in scientific and practice activity of Anna Freud. The purpose of the article is to uncover the ideas of psychoanalytic pedagogy by Anna Freud, who was one of the first to start using psychoanalysis for educational purposes. The article describes the life and professional path of Anna Freud. The key works and the views of Anna Freud on the interaction of psychoanalysis and pedagogy were briefly reviewed. The features of the private school «Hietzing» (1926-1932) and the Hampstead Orphanage (1940), created by Anna Freud in Vienna and
London, respectively, are investigated. It was established that Anna Freud supported the concept of free education Maria Montessori, criticized directive pedagogy and the classical education system. Anna Freud's key ideas were to give the child the freedom to develop, to elevate the authority of the teacher in society, and to increase the focus on the social environment. She saw the position of the teacher in the formation of an «ideal Self», which will be equated by each student. Only in such conditions is normal mental and physical development of the students possible. Anna Freud assured that the realization of educational influences on the child depends first of all on her age, and the educational system is adjusted according to the character and level of development of the student. In doing so, the teacher should not assume the role of the student's parents. Excessive emotional support, the teacher's desire to please the child, on the contrary, will alienate the child from the teacher. It was concluded that, thanks to the ideas of psychoanalysis, the education system began to pay attention to the inner world of the student and teacher, the internal conflicts of the individual and the need to work with the sphere of the unconscious.

Key words: psychoanalytic pedagogy, formation, psychoanalysis, education, Anna Freud.

Постановка проблеми. Упровадження Концепції «Нова українська школа» спонукає багатьох освітян до розробок альтернативних методів роботи 3 учнями. Зокрема, в умовах популяризації педагогіки партнерства на особливу увагу заслуговує концепція психоаналітичної педагогіки, яка була заснована 3. Фрейдом ще на початку XX ст.

Аналіз наукових досліджень і публікацій. Проблему розвитку ідей психоаналітичної педагогіки неодноразово розкривали у своїх дослідженнях Н. Бурлакова $[1 ; 2]$, О. Петренко, М. Рожков, Т. Хомуленко, І. Шпичак та ін. Однак на тлі загального вивчення психоаналітичної педагогіки, недостатньо обгрунтованим $є$ внесок окремих дитячих психоаналітиків, як-от Ф. Дольто, М. Кляйн, А. Фрейд та ін., які неодноразово робили спроби інтегрувати психоаналіз в освітню практику.

Мета статті - охарактеризувати ідеї психоаналітичної педагогіки Анни Фрейд, яка однією 3 перших розпочала застосування психоаналізу у виховних цілях.

Виклад основного матеріалу. Професійне становлення молодшої доньки 3. Фрейда відбувалося переважно у домашніх умовах. Зважаючи на єврейське коріння Анни, єдиним місцем для опанування майбутньої професії були педагогічні курси, 
а не університет, для вступу в який необхідно було закінчити гімназію. Уперше з теорією психоаналізу Анна ознайомилася у 13-річному віці, а власну практику розпочала, спостерігаючи за дітьми друзів. На початку своєї діяльності їі передусім цікавили питання техніки дитячого аналізу, що пояснювалося постійними суперечками фахівців у цій новій галузі науки.

Після Першої світової війни у Відні, де на той час мешкала родина 3. Фрейда, педагогічно орієнтований психоаналіз розвивався досить активно. Цьому сприяли ідеї швейцарського пастора О. Пфістера, що розробляв методи педагогічного аналізу, австрійського психоаналітика і педагога А. Айхорна, який працював консультантом при Віденській службі у справах молоді, а також австрійського психолога та психоаналітика 3. Бернфельда, завдяки зусиллям якого у Відні у 1919 році було створено експериментальний дитячий будинок «Баумгартен». У цей період неабиякий вплив на А. Фрейд мала Г. Гуг-Гельмут, яка першою започаткувала використання ігор як ключового методу розуміння дитячої психіки й довела, що розумова діяльність дитини більше перебуває під впливом почуттів, аніж інтелекту, а як наслідок - завдяки грі дитина легко відкриває свої почуття [8].

У 1922 р. Анну Фрейд було прийнято до Віденського психоаналітичного товариства, однак чимало колег критикували іiі за відсутність медичної освіти та однобокість поглядів. Незважаючи на це, у 1926 р. у Відні вона відкриває приватну школу «Хітцинг» (Hietzing, 1926-1932), в якій навчалися діти вихователів і прихильників психоаналізу, а в 1927 р. виходить друком іiї перша книга - «Вступ до техніки дитячого аналізу». Опираючись на власні клінічні дослідження, А. Фрейд стверджувала, що психоаналітична робота 3 дорослими суттєво відрізняється від роботи 3 дітьми, адже при цьому перевага надається не методу вільних асоціацій, а спостереженням за ігровою і творчою діяльністю дітей

Коли у 1932 р. школа «Хітцинг» припинила свою діяльність, А. Фрейд переходить працювати до педагогічної консультації при Віденській амбулаторії, де, за направленням лікарів та вчителів, безкоштовно консультувала дітей і підлітків із малозабезпечених родин $[6$, c. 13]. У ці роки вона знайомиться з ідеями М. Монтессорі, про систему освіти якої ії батько, 3. Фрейд, зауважив: «Якби кожен навчався в школі Монтессорі, їм би не знадобився Фрейд». За зразком однієї із таких шкіл Анна у 1937 р. відкриває у Відні дитячий садок «Будинок дітей», в якому виховувалися переважно немовлята і де вона спостерігала за специфікою психологічного відокремлення дитини від батьків [9].

Посилення фашистських настроїв, арешт і допит гестапо змусили родину 3. Фрейда у 1938 р. емігрувати із Відня до Лондона. Із початком Другої світової війни А. Фрейд організовує в Лондоні Хампстедський дитячий будинок (1940р.), де на той час діяли три відділення: ясла, садок та інтернат для евакуйованих лондонських дітей віком від 3 до 6 років. Працюючи тут, Анна поставила собі за мету розробити прикладний, орієнтований на виховання психоаналіз. Основними напрямами роботи дитячого будинку були: корекція фізичних і психічних наслідків війни в дітей; профілактична робота 3 дітьми війни в умовах їх розставання 3 батьками; дослідницька робота 3 колегами і навчальна 3 вихователями і медсестрами [2, с. 47-48]. Усі свої напрацювання і спостереження А. Фрейд згодом представила в праці «Особистість в екстремальних умовах» [5], яка вийшла у співавторстві з Д. Берлінгем.
У 1944 р. Анну Фрейд призначають Генеральним секретарем Міжнародної психоаналітичної асоціації, а з 1973 р. вона стає ії почесним президентом. У 1947 р. при Хампстедському дитячому будинку вона організовує 3-річні курси з підготовки фахівців із дитячого психоаналізу. Неабияка популярність цих курсів і постійне збільшення кількості студентів спонукали дослідницю до відкриття у 1952 р. на базі Хампстедського дитячого будинку ще й спеціалізованої клініки, яку вона очолювала впродовж 1952-1982 років. У 1984 р. цьому закладові було присвоєно ім'я Анни Фрейд.

Посилаючись на результати своїх досліджень, А. Фрейд переконувала, що психоаналітична робота 3 дітьми потребує спеціальної техніки, адже психіка дитини ще недостатньо сформована, а як наслідок рішення стосовно проходження дитиною психоаналізу, звичайно, приймають батьки, а отже, завдання дитячого психоаналітика, як і вчителя, полягає у дотриманні певних правил, найважливіші серед яких: значну увагу приділяти родинним відносинам та оточенню дитини; не бути байдужим і зайняти місце «Я-Ідеалу» в житті учня. Таким чином, лише налагодивши емоційні стосунки 3 дитиною, ставши авторитетом в їі очах, психоаналітик (як і вчитель) зможе займатися іiі вихованням [4, с. 9-10].

Організація Хампстедського дитячого будинку, курсів і клініки стало справою життя А. Фрейд. Працюючи там, вона змогла розкрити свої психоаналітичні ідеї та створити умови для їх поширення. Як і колись, Хампстедська клініка і сьогодні нараховує чотири відділеннях: клінічне; дослідницьке; відділення взаємодії з представниками інших наукових дисциплін; превентивної й педагогічної роботи. Останнє включає дитячий садок для 3-6-річних дітей із неблагополучних родин, а також невелику групу сліпих дітей [3, с. 19].

Ключові ідеї А. Фрейд були розкриті нею у працях «Вступ до техніки дитячого психоаналізу» (1927), «Вступ до психоаналізу для вчителів» (1930), «Вихователь і невроз» (1932), «Виховання маленької дитини з психоаналітичної точки зору» (1934), «Я і захисні механізми» (1936), «Маленькі діти у військовий час: рік роботи в дитячому будинку» (1942) та ін. Усі вони були написані нею після публічних презентацій чи лекцій. Так, праця «Вступ до техніки дитячого психоаналізу» включала спочатку чотири лекції, прочитані Анною у Віденському психоаналітичному інституті, а в 1929 р. була доповнена доповіддю «Про теорію дитячого психоаналізу», прочитаною у 1927 р. на XX Міжнародному психоаналітичному конгресі (Інсбрук, Австрія).

Книга «Вступ до психоаналізу для вчителів» також включала чотири окремих лекції, які були прочитані А. Фрейд у 1928 р. для вихователів дитячих садків Відня. У 1929 р. на сторінках «Журналу психоаналітичної педагогіки» була опублікована лекція «Відносини між психоаналізом і педагогікою», в якій А. Фрейд прагнула зацікавити основами психоаналізу фахівців, які ніколи раніше не використовували його у своїй професійній діяльності. На думку А. Фрейд, виховний вплив на дитину необхідно обмежити, це передусім сприятиме формуванню толерантного «Над-Я». Водночас вона зауважувала, що певні заборони, які дорослі використовують стосовно дітей, особливо тих, що виховуються у неблагополучних родинах і позбавлених батьківської опіки, зрештою $є$ небезпекою для формування їх соціальної поведінки. Таким чином, А. Фрейд дотримувалася 
«золотої середини» між надто вільним і надто суворим вихованням, радила шукати компроміс між тотальним задоволенням i фрустрацією. Лише завдяки цьому психоаналітична педагогіка зможе стати інструментом у вихованні самодостатньої і вільної людини [3, с. 29].

Неабияке значення А. Фрейд надавала питанням соціального становища вчителя. Вона передусім звертала увагу на суперечності між суспільними вимогами до вчителя і рівнем його доходів; між неналежним ставленням до роботи шкільного вчителя i суспільною шаною до викладачів університетів. Єдиною свободою в роботі вчителя вона вважала вибір методів педагогічної взаємодії, а ще була переконана: яке б виховне завдання не ставили перед учителем, він виконував його з однаковою наполегливістю. При цьому суспільство завжди було переконане, що поставлена мета $є$ для вчителя легкодосяжною, а як наслідок - у випадку невдачі буде винен учитель, а не система виховання в цілому. Шукаючи виправдання будь-яким звинуваченням, учителі завжди зверталися до психології, однак виправдати себе вчителям не вдасться доти, доки психологи не досягнуть реальних успіхів у розумінні кожної дитини [6, с. 334-341].

Незважаючи на те, що чимало сил А. Фрейд доклала, аби впровадити психоаналітичну теорію у педагогічну практику, однак надії, які вона покладала на психоаналітичну педагогіку, на жаль, не виправдалися. У праці «Норма і патологія у дитинстві. Оцінка дитячого розвитку» (1965) вчена зазначала: «... діти, які виховуються в нових умовах, можливо, чимось і відрізняються від своїх попередників, однак вони не позбавлені тривог і конфліктів, а отже, так само як і вони страждають від невротичних і психічних розладів» [7, с. 17].

У своїх дослідженнях А. Фрейд акцентувала увагу як на проблемах внутрішнього світу дитини, так і на соціально-психологічній взаємодії в родині. Вона наполягала на розділенні понять «батьківська турбота» та «виховання». При цьому перше трактувала як «взаємодію, в ході якої дорослий задовольняє всі життєві потреби дитини, яка натомість йому нічого не винна», а друге - як «один із видів соціального впливу, що визначає намір батьків щодо формування ідеального образу дитини в майбутньому» та «боротьбу зі звичками, які відрізняють дитину від дорослого, намагання підкорити дитину наявним суспільним нормам» [2, с. 50].

Підтримуючи ідею про те, що культура передбачає пригнічення індивідуальних проявів, А. Фрейд розмірковує над тим, що може трапитися 3 дитиною, якщо їй дозволити розвиватися без зовнішнього (виховного) впливу. 3 одного боку, матимемо зразкове втілення ідей Ж.-Ж. Руссо і М. Монтессорі, які вважали, що дорослому не варто втручатися у процес природного розвитку дитини, а з іншого - за відсутності адекватних виховних впливів дитина не лише не зможе стати повноцінною особистістю, а й не рахуватиметься з інтересами інших.

Важливе місце в дослідженнях А. Фрейд займає і проблема формування «Над-Я» дитини, що відбувається внаслідок протиріччя між бажаннями дитини i прямо протилежними бажаннями дорослого, який прагне досягти свого завдяки різним заборонам, покаранням і залякуванням. Так, дорослий залякує дитину не лише фізичними покараннями («не тягни палець до рота, бо відріжу»), а й психічними утисками («я не любитиму тебе і знайду собі іншу дитину»). При цьому представлені вище загрози надзвичайно тісно пов'язані між собою, адже будь-яка людина боїться покарання від значимого для неї об’єкта.
Тому, аби покарання були для дитини дієвими, дорослий (батько, вчитель та ін.) має бути для неї значимим. Лише у цьому випадку дитина поступово ототожнюватиме себе з дорослим, прийматиме його цінності й, зрештою, визнає їх справедливими. Отже, чим позитивнішим буде процес інтроекції, тим більше задоволення отримають дорослі від наслідків своїх виховних впливів на дитину. При цьому, ставши «зручною» для дорослого, дитина приносить у жертву свої здібності, ясний погляд і світлий розум. Безпосередня, допитлива і жвава особистість через ідентифікацію з дорослим i кардинальну зміну своїх поглядів на протилежні, зрештою, опиняється загнаною у раціональні рамки існуючої системи. Як наслідок - дитина, замість того, щоб розуміти, що світ не завжди може бути досконалим, прагне вбудувати свій новий образ в «ідеологічну модель» дорослого життя та уподібнити себе вимогам і рольовим очікуванням інших [6, с. 33-40].

Педагогічні погляди А. Фрейд насамперед грунтувалися на тому, що, опираючись на розуміння внутрішнього світу дитини у певний віковий період, можна розраховувати на ефективний виховний вплив. Тобто, реалізація виховних впливів на дитину передусім залежить від ії віку, а система освіти вибудовується відповідно до характеру і рівня розвитку учня. Зокрема, у підлітковому віці спостерігається внутрішньоособистісний конфлікт між «Я» (бажаннями дитини) i «Над-Я» (вимогами школи, суспільства). Зважаючи на це, можливості виховання визначаються винахідливістю дорослих. При цьому помиляються ті, хто перебуває в опозиції до дітей. Саме в цей важливий для дитини період дорослий має перейнятися ії становищем, віднайти можливі причини внутрішнього конфлікту, в дечому змінити свою поведінку, тобто намагатися створити «коаліцію» 3 іiї «Над-Я». Лише у цьому випадку можна здобути перемогу соціальної адаптації над внутрішніми потягами дитини [6, с. 46].

Створення «коаліції» між учителем і «Над-Я» дитини можливе також за умови, якщо вчитель не перейматиме на себе роль батьків учня. Надмірна емоційна підтримка, бажання педагога сподобатися i «прив'язати» дитину до себе, навпаки, відштовхне дитину від нього. Таке перенесення дитячих реакцій на вчителя замість батьків не лише негативно вплине на нього, а й загалом ускладнить процес навчання. Завдання вчителя при цьому - формувати у психіці учня образ авторитетного дорослого, оскільки на тлі цього авторитету виникає образ «знаючого іншого» - ідеального вчителя, який не тільки знає і може набагато більше, ніж батьки, а й контролює роботу значної кількості учнів, на відміну від батьків, які мають вплив лише на одну дитину [1, с. 32].

Опираючись на багаторічний досвід практичної взаємодії з дітьми, А. Фрейд переконує, що класична система виховання руйнує особистість дитини, породжує внутрішні конфлікти, обмежує їх здатність відкрито проявляти свої почуття. Учень завдяки такому впливу не відчуває особливої радості дитинства, адже опиняється «затиснутим» у соціальні рамки. Зрештою А. Фрейд підсумовує, що найкраще у даному випадку - пожертвувати наявними нормами і надати дитині можливість розвиватися природно. При цьому вчителеві необхідно повсякчас тримати баланс між тотальною вседозволеністю та наявними обмеженнями [6, с. 51-53]. 
Розмірковуючи над значенням психоаналізу для педагогіки, А. Фрейд виокремила такі чотири його позитивні сторони: 1) завдяки психоаналізу було обгрунтовано недоліки та слабкі сторони притаманної тому часові освітньої традиції; 2) під впливом психоаналізу було узагальнено наявні знання про складність взаємодії між дітьми і дорослими; 3) психоаналіз створив підгрунтя для виправлення допущених батьками помилок у вихованні дітей; 4) саме психоаналізу належить роль першовідкривача у питанні врегулювання внутрішніх конфліктів між учнями та педагогами [6, с. 55]. Таким чином, на думку А. Фрейд, будь-яку взаємодію з дитиною (навчання, виховання, психокорекція тощо) неможливо уявити без злагодженої емоційної взаємодії, і чим складнішою при цьому є їі мета, тим міцнішою має бути ця взаємодія [4, с. 427].

Висновки. Постать А. Фрейд і сьогодні, на початку XXI століття, залишається однією з ключових у розбудові психоаналітичної педагогіки. Розроблена нею під впливом ідей 3. Фрейда та М. Монтессорі концепція, ставила під сумнів авторитарну педагогіку і класичну систему освіти як таку, що утискала таланти, заперечувала самовираження дитини, закликала до поширення внутрішніх конфліктів. Будучи за фахом учителем молодших класів, Анна Фрейд пропагувала поширення психоаналітичних ідей серед учителів. Свій метод роботи з дітьми вона протиставляла концепції М. Кляйн, розвідки якої стосувалися переважно роботи з немовлятами і дітьми раннього віку.

Зважаючи на вищевикладене, перспективи подальших наших досліджень вбачаємо у вивченні ідей кляйніанського психоаналізу та його внеску в педагогічну практику.

\section{СПИСОК ВИКОРИСТАНОЇ ЛІТЕРАТУРИ}

1. Бурлакова Н. С. Детский психоанализ: школа Анны Фрейд / Н. С. Бурлакова, В. И. Олешкевич. - М. : Издательский центр «Академия», 2005.

2. Бурлакова Н. С. Психоаналитическая педагогика: открытия, надежды и разочарования / Н. С. Бурлакова // Современное дошкольное образование. -2009 . - № 3. - С. 46-52.

3. Энциклопедия глубинной психологи : в 3 т. Т. 3. Последователи Фрейда. - М. : Когито-Центр, МГМ, 2002. - 410 с.

4. Фрейд А. Детский психоанализ / А. Фрейд. СПб. : Питер, 2003. - 477 с.

5. Фрейд А. Война и дети / А. Фрейд, Д. Берлингем ; пер. с англ. Е. Уманской // Развитие личности. - 2004. - № 3. - С. 184-208.

6. Фрейд А. Теория и практика детского психоанализа / А. Фрейд. - М., 1999. - Т. 1. - 384 с.

7. Freud A. Wege und Irrwege in der Kinderentwicklung. - Bern, Stuttgart: Huber und Klett, 1968.

8. Hug-Hellmuth H. Kinderpsychologie und Pädagogik // Jahrbuch für Psycho-analytische und psypathologische Forschungen. - 1914. - № 6. - P. 398.

9. Trabalzini P. Maria Montessori e i rapporti con Sigmund Freud // Annali di storia dell'educazione e delle istituzioni scolastiche. 2018. - № 25. P. 146-162.

Дата надходження до редакиіï: 03.08.2019 р.
УДК 371.2(09)

DOI: $10.37026 / 2520-6427-2019-100-4-88-89$
Ярослав СПІВАК,

кандидат педагогічних наук, доиент кафедри менеджменту ДВНЗ «Донбаський державний педагогічний університет»,

м. Слов'янськ Донеиької області

\section{АКМЕОЛОГІЧНІ АСПЕКТИ ПРОФЕСІЙНОЇ ПІДГОТОВКИ СОЦАЛЬНИХ ПРАЦІВНИКІВ В УМОВАХ НЕПЕРЕРВНОЇ ОСВІТИ}

У статті розкрито особливості засвоєння майбутніми сочіальними працівниками теоретичних засад неперервної освіти в ході вивчення курсу «Андрагогіка з основами акмеологї̈. Студенти оволодівають категоріальним апаратом з означеної сфери, усвідомлюють сутність безперервної освіти як системи, щуо охоплюе всі рівні освіти. Важливим при иьому є акмеологічний підхід до педагогічної підготовки майбутніх сочіальних працівників, щчо полягає у виявленні природного потенціалу кожної людини та створенні умов для подальшого вияву їх творчих інтересів та обдарувань.

Ключові слюва: акмеологічний підхід, кониептуальні положення, функції, принщипи, неперервна освіma, особистість.
В статье раскрыты особенности усвоения будуциими социальньыми работниками теоретических основ непрерывного образования в ходе изучения курса «Андрагогика с основами акмеологии». Студенты овладевают категориальным аппаратом с обозначенной сферы, осознают сущность непрерывного образования как системы, охватьвваюей все уровни образования. Важным при этом является акмеологический подход к педагогической подготовки будущиих сочииальных работников, что заключается в выявлении природного потенииала каждого человека и создании условий для дальнейшего проявления их творческих интересов и дарований.

Ключевые слова: акмеологический подход, концептуальные положения, функции, принщипь, непрерывное образование, личность. 